\title{
1992 Earth Summit: What Role for Concerned Citizens?
}

When Prime Ministers and Presidents gather for the first-ever Earth Summit - the United Nations Conference on Environment and Development (UNCED), set for 1-12 June 1992 in Rio de Janeiro - they will make decisions with wide-ranging impact on the world's ecology and economy. Global warming, stratospheric ozone depletion, air and water pollution, deforestation, toxic wastes, and endangered species, are only a few of the myriad environmental and allied problems that are slated for consideration at the Conference. Underlying these are the highly complex, political issues of sustainable development: how to promote continuing economic growth in all countries without poisoning or exhausting the environmental resources that peoples everywhere need in order to live.

While the main players on the Summit's stage will be Heads of State, activists concerned with issues of environment and development will also play an essential role in the process. As Maurice Strong, the SecretaryGeneral of the Conference, has stated, the outcome of the Summit will largely depend on its ability to mobilize world opinion - as wide-scale citizen involvement can do. That alone can encourage Governments to agree to necessary but politically difficult policy-changes. "Public awareness', says Mr Strong, 'is the source of political will; political will is the key to the success of the Conference.'

As with all UN conferences, the decisions adopted at the Earth Summit will be shaped far in advance, during meetings of the Preparatory Committee and its Working Groups. From the start of preparations for the Summit, the importance of the knowledge and opinions of nongovernmental organizations (NGOs), other activists, and independent-sector experts, has been recognized by Conference organizers.

In a move that is almost unprecedented within the Organization, the United Nations General Assembly has decided that any NGO with 'relevance' and 'competence' in the area of environment and development will be able to take part in preparations for the Summit. Specifically, they will address meetings of the Conference's Preparatory Committee, make written presentations, and participate in the discussions of the Committee's Working Groups. NGO's will not take part in the Committee's negotiations nor vote on its decisions. The Committee held its third series of meetings from 18 March to 12 April in Geneva.

On the national level, many NGOs are working to have their views included in the national report that each country will present to the Conference, due to be submitted by July 1991. A number of ad hoc national NGO coalitions have been formed to pool their expertise and influence in that task, and some NGOs are also participating in national advisory committees for the Conference, or lobbying their Governments on related issues. Those interested in getting involved in national NGO efforts should contact their environment ministry, their national coalition, or Mr Lars Hyttinen, the Director of National and Regional Activities for the UNCED Secretariat.

Scores of NGOs and independent-sector groups have already begun gearing up for the Summit, and an International Facilitating Committee has been formed to coordinate efforts world-wide. The Geneva-based Centre for Our Common Future is playing a major organizing role and puts out a comprehensive newsletter, Network '92. The Conference of NGOs in Consultative Status with the UN Economic and Social Council (CONGO), in Geneva, and the Environment Liaison Centre International (ELCI), in Nairobi, are also actively coordinating world-wide preparations for the Summit.

Many international and regional meetings are to be held between now and June 1992, to examine environment and development issues from the point of view of industrialists, scientists, women, youth, and indigenous peoples, among others. A global NGO conference - organized by ELCI and hosted by the French Government - it scheduled for 17-20 December 1991 in Paris. It is expected that over 1,000 NGOs will meet there to prepare a position paper for the Summit. During the Summit itself, thousands of NGOs and independent-sector activists will conduct a full-scale parallel Conference in Brazil.

To act as liaison with independent-sector groups, the secretariat of the Conference has appointed Yolanda Kakabadse, formerly with Ecuador's Fundación Natura, to deal exclusively with NGO relations. The United Nations Non-Governmental Liaison Service (NGLS) is also very active in informing NGOs about the preparatory process for UNCED. Out of their Geneva offices, the Conference secretariat puts out a newsletter, Earth Summit News, and NGLS publishes $E \& D$ File 1992.

What will hopefully come of this global mobilization? The Conference is expected to produce:

- An Earth Charter that will embody basic principles which must govern the economic and environmental behaviour of peoples and nations to ensure 'our common future';

- Agenda 21, a blueprint for action in all major areas affecting the environment/development relationship, which will establish programmes, define targets, and fix objectives against which progress can be measured over the next decades;

- The means to make available to developing countries the additional financial resources and environmentallysound technologies which they need to make environmental considerations part of their development policies - likely to be a politically difficult issue;

- Agreement on what international institutions should be created or strengthened to carry out these goals; and

- Conventions on climate change, biological diversity, and forestry, which may be negotiated prior to the Conference and then signed or agreed to in Brazil.

The Earth Summit is envisaged as an agent of profound change that will move environment into the centre of economic decision-making and possibly alter the behaviour not only of Governments but also of whole economic sectors and individual consumers. But only with support from governments, NGOs, businesses, trade unions, citizen groups, and the public at large, will the Summit fulfil its ambitious objectives.

JULIE I. THOMPSON, Project Manager
UN Information Programme on Environment
\& Development
United Nations Plaza
NY 10017
USA.

